\title{
Design and Analysis of Online Micro-course of Garden Architecture Design Based on CPC Model
}

\author{
https://doi.org/10.3991/ijet.v12i07.7214 \\ Lili Liu \\ School of Architecture, Chang'an University, Xi'an, China \\ $13891858602 @ 163 . \mathrm{com}$
}

\begin{abstract}
In the network information age, micro-course is a brand-new teaching method which integrates conciseness, vividness, visualizability and distinctiveness. It is also a means of educational informationization. Especially in architecture design course, micro-course has been effectively applied. Based on CPC model, online micro-course of Garden Architecture Design was constructed again by combining patent $2 \mathrm{D}$ code technology in this paper. The design and analysis of online micro-course of Garden Architecture Design based on CPC model can basically achieve classroom flipping, promote equal interaction between teachers and students, enhance communications among classmates, feedback and evaluate teaching effect in time, promote students' learning interest, change students' learning attitude and boost their academic performance so as to reach the expected teaching objective.
\end{abstract}

Keywords - CPC model, garden architecture design, micro-course, 2D code

\section{Introduction}

Micro-course is a modern teaching means which develops with the internet technology. It is a well-designed and developed digital learning platform for the specific subject knowledge and teaching links, and takes minitype streaming media teaching video as the carrier [1]. Its biggest characteristics include short and rich contents, distinct and interesting themes, scenario, visualization and interestingness. Microcourse changes the learning mode. With it, students can carry out mobile and fragmented flipped study and meet individual learning needs [2]. Thus, micro-course has gained consistent good reputation from teachers and students, and plays an important role in education and teaching. Besides, it develops rapidly in the network age. Microclassroom is opposite to traditional classroom. To be straightforward, microclassroom minimizes the traditional classroom and advocates modularized and fragmented teaching. Maybe 5-10min content transmission is alright [3]. Internet online micro-classroom is opposite to internet offline micro-classroom and stresses networkbased classroom form rather than traditional face-to-face teaching. Internet online micro-classroom aims to let learners to acquire knowledge from PC terminal or smartphone terminal more conveniently [4]. 


\section{Research Progress Review}

George et al. applied the continuing education micro-course called "Friending Facebook" in medical education course to impart existing medical and healthcare techniques to health workers in the form of micro-course. The course was universally accepted, and the participants recognized several tools which might be usefully in their career, including news aggregators, Google Alerts, and-if used responsiblysocial networking sites such as Facebook [5]. Jacoby [6] put forward this project to develop a self-contained web-based micro-course which satisfies genetics and genomics abilities for undergraduate nursing education. Hence, it can be used in the baccalaureate nursing program. After the experiment ended, the test score of students before the intervention was $49.3 \%$, while the mean test score of students completing micro-course-based teaching was $88.7 \%$. The teaching form of micro-course can significantly improve students' scores.

In recent years, micro-course has been more and more widely applied in design and architecture curses, and has gained god teaching effects. In addition, the researches on design and architecture micro-curses have become increasingly deep, and there are new findings and progress [7]. He [8] combined Revit series software with the microcourse of architecture design major, and utilized Revit series software to help students simulate architecture design, construction and maintenance. The results show that the teachers' active application of Autodesk Revit Architecture software to make or demonstrate modeling in teaching Architectural Recognition Graph can make students deepen the cognition of building components, accessories and materials and improve the teaching effect. Li et al. [9] considered the defects of information-based teaching resources (such as fragmentization, entertainment, shallow reading and randomness) and proposed to integrate these teaching resource fragments and make them into specific micro-course videos and to apply them in micro-course teaching of architecture design so as to make resources visual, standard, shared and interactive. The result has proven that such method can make students have the initiative in study. Peng [10] introduced micro-course mode in independent learning training of design majors, analyzed the basic principle and functional module of the training platform, designed and implemented training video recording, uploading, playing, evaluation and search functions as well as established the training resource library, evaluation resource library and learning resource library. This well promoted students' comprehensive skills of independent study and also offered convenience for overall planning and scientific management of teaching resource library.

In the process of micro-course application and development, we have found that there are some limitations and defects. Firstly, most schools make teaching resource library public on campus website for teachers and students to share the learning and teaching resources. In the past, teachers and students first retrieved the resources and then downloaded them. Thus, students need to find out the contents they need from the database with mass data and information, which wastes time and energy. Secondly, teaching resource utilization rate of micro-course is low, and learning initiative of some students is low. Micro-course resource construction breaks away from actual teaching application. Moreover, network teaching system which takes the course as 
the unit has such limitations as high application and development cost, long development cycle, poor openness, large construction difficulty and repeated construction.

Based on the above, $2 \mathrm{~d}$ code technology was creatively applied in combination of multimedia teaching technology in this study, which could exempt the troubles of information retrieval and URL input and offer the system based on 2D code through which students can fast enter the desired webpage with one button so as to gain the learning content. Besides, based on CPC model, this paper designed and analyzed online micro-course of Garden Architecture Design as well as achieved breakthrough and innovation of traditional multimedia teaching.

\section{Theoretical Basis}

CPC [11] (Customer-Product-Channel) model is a common classic model in the management field. It is mainly used for channel operation management. It mainly coordinates the relationship among channel, customer and product, and meets customers' real needs through displaying external attributes of products in the channel. In marketing management, this model is applied for feature analysis and relationship adjustment, and the management process is scenarized. In this way, the products needed by customers can be delivered to customers easily through the proper channel.

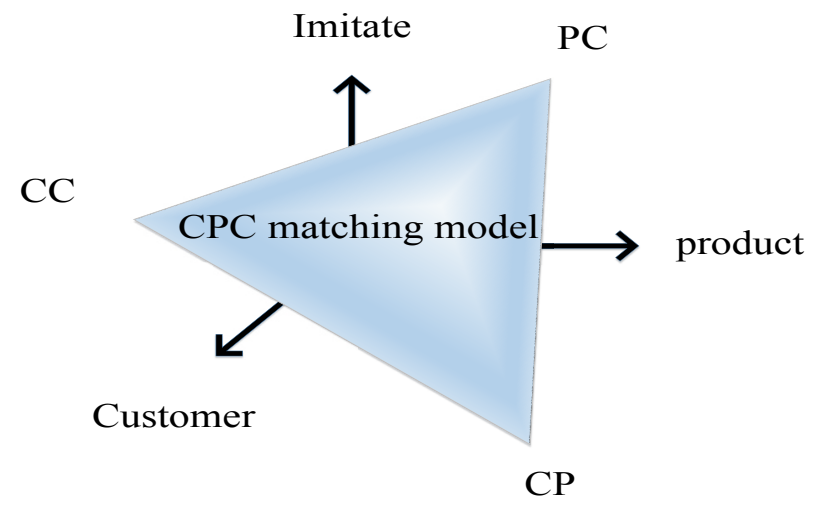

Fig. 1. CPC model of channel management

However under the background of mobile internet age, 3 elements in CPC model are given broad meanings in order to adapt to the age development. Customer demand presents the features of diversification and individuation. The channel presents the trend of transformation from physical store to online store and virtual community with the internet development. The product also shows the trend of replacing traditional manufacturing industry with business/service with the asset-light property. Hence, more network information technology elements are injected in CPC model in the internet age.

Usually, the model applies sorting algorithm, i.e. logistic regression algorithm, to analyze customer attribute feature, mine customers' largest needs, choose the proper 
products and deliver the products through an appropriate channel. Logistic regression analysis belongs to statistical analysis algorithm, and studies the correlation between explanatory variable and explained variable, i.e. customers' matching model for products. For example, content and technology implementation in the micro-course platform is deemed as the display channel to analyze the relationship between the demand and feedback of customers (students) and products (theoretical knowledge and skills).

We suppose the ideal value of explained variable is 1 . The probability $\mathrm{P}$ is modeled with general linear regression model. In realistic conditions, the probability value of explained variable in the regression equation is within $0-1$. So, the general form of regression equation is

$$
p=\beta_{0}+\beta_{1} x_{1}
$$

In the actual condition, it is very hard for the explained variable to reach the ideal value. So, transformation treatment is conducted for the probability $\mathrm{P}$ to make its value scope keep consistent with the linear regression model.

Firstly, $\mathrm{P}$ is transformed into $\Omega . \Omega$ is occurrence ratio, i.e. the ratio of occurrence probability to nonoccurrence probability. Then, $\Omega$ is transformed into $\operatorname{In}(\Omega)$, i.e. Logit P.

$$
\begin{gathered}
\Omega=\frac{p}{1-p} \\
\operatorname{In}(\Omega)=\operatorname{In}\left(\frac{p}{1-p}\right)
\end{gathered}
$$

After the transformation, the probability value scope will keep consistent with the linear regression model. Besides, Logit model is established. The regression equation is

$$
\operatorname{Logit} P=\beta_{0}+\sum_{i=1}^{k} \beta_{i} x_{i}
$$

Substitute $\Omega$ and gain

$$
\operatorname{In}\left(\frac{p}{1-p}\right)=\beta_{0}+\sum_{i=1}^{k} \beta_{i} x_{i}
$$

Then

$$
\begin{aligned}
& \frac{p}{1-p}=\exp \left(\beta_{0}+\sum_{i=1}^{k} \beta_{i} x_{i}\right) \\
& P=\frac{\exp \left(\beta_{0}+\sum_{i=1}^{k} \beta_{i} x_{i}\right)}{1+\exp \left(\beta_{0}+\sum_{i=1}^{k} \beta_{i} x_{i}\right)}
\end{aligned}
$$


Formula 7 is sigmoid function with the value of 0 and 1 . The probability that the value of explained variable is 0 or 1 can be figured out. When the probability of 0 is less than that of 1 , the explained variable falls into o class. On the contrary, it falls into 1 class. In a sense, Logistic regression algorithm belongs to dichotomy probability algorithm. When Logistic regression equation is confirmed, $\Omega=\exp \left(\beta_{0}+\sum_{i=1}^{k} \beta_{i} x_{i}\right)$ is gained. Then, comparison can be carried out.

2D code technology [12] is a kind of recognition technology which is invented with the development of network technology. In traditional multimedia teaching, search engine is usually used to search teaching resources. Besides, keyword, title, author, theme and full text are applied to search resources, then preview online, download and save. Information resource retrieval methods and forms are various, but they have a common point, i.e. to input key information. The information is fuzzy and uncertain. In the information database with huge resources, the process of positioning accurate contents is tedious, like looking for a needle in a bottle of hay. Finally, the ideal result may not be gained.

2D code technology avoids the tedious resource retrieval process. It is just necessary to scan the corresponding $2 \mathrm{D}$ code with the reader to enter the resource library and find out the contents quickly. The webpage layout with 2D code is tidy, and hierarchical tiles under general page are omitted. In addition, any URL input is not needed. Learners can study anytime and anywhere.

Teaching resource library contents implemented by 2D code technology consist of multimedia courseware library, course standard library, explanation-based online course library, question answering tutorship system library, material and case library etc. These resources can be intelligently and automatically classified to generate text, page, picture, animation and video when they are scanned. Students can flexibly choose the content.

\section{Online Micro-course Teaching Platform Construction based on CPC Model for Garden Architecture Design}

\subsection{Micro-course teaching platform construction}

Based on CPC model, online micro-course teaching platform for Garden Architecture Design was designed, constructed and analyzed by combining 2D code technology in this paper. The total class hours of Garden Architecture Design micro-course is 113, including architecture design theory, methods and skills of garden architecture design, pavilion design, service-based architecture design and design of garden architecture facilities etc.

In the online micro-course system of Garden Architecture Design, micro-course platform and its implementation technology are a kind of channels, and the carriers to serve education and teaching. The analysis of channel and platform can help better understand the functions of micro-course platform. The products of micro-course include all kinds of knowledge, information, resources and learning achievements 
stored in the micro-course resource library. The customers in micro-course are students in the teaching system. The application effect of online micro-course platform of Garden Architecture Design can be verified through analyzing students' attributive characteristics, exploring their different needs for course study and seeking the feedbacks of their learning attitude.

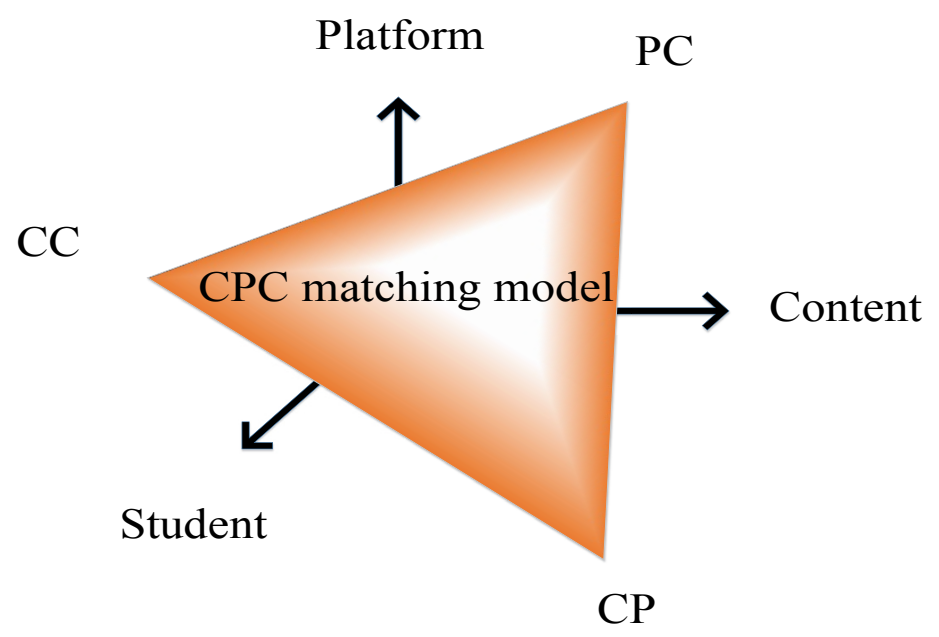

Fig. 2. CPC model of micro-course

Three important roles in online micro-course construction process were fully considered by applying CPC theory in this paper, including platform (content, technological carrier), students (knowledge receivers) and teachers (product providers). It is necessary to investigate students' different demands for teaching resources, and teachers meet such demands. In this way, the scientific and thorough online microcourse system platform of Garden Architecture Design was constructed. Logistic regression algorithm was applied to score students' learning resources and content situations. For example, for the extended content of Garden Architecture Design micro- course, due to the limited class hours, students were required to choose garden architecture in a few countries for design and improvement. Students could choose garden architecture information of corresponding countries and let them enter the micro-course resource library according to their resource needs. They could score and vote according to their own needs. Through Logistic regression analysis, the garden architecture of top 4 countries and their corresponding probabilities are gained as follows: Chinese natural landscape architecture (0.59), Italian tableland-type villa garden architecture (0/42), French palace-type garden architecture (0.36) and British natural scenery garden architecture $(0 / 32)$. Here, the probabilities are mutually independent. Students may choose from the high probability to the low probability. The following figure shows the overall frame structure of micro-course system of Garden Architecture Design. 


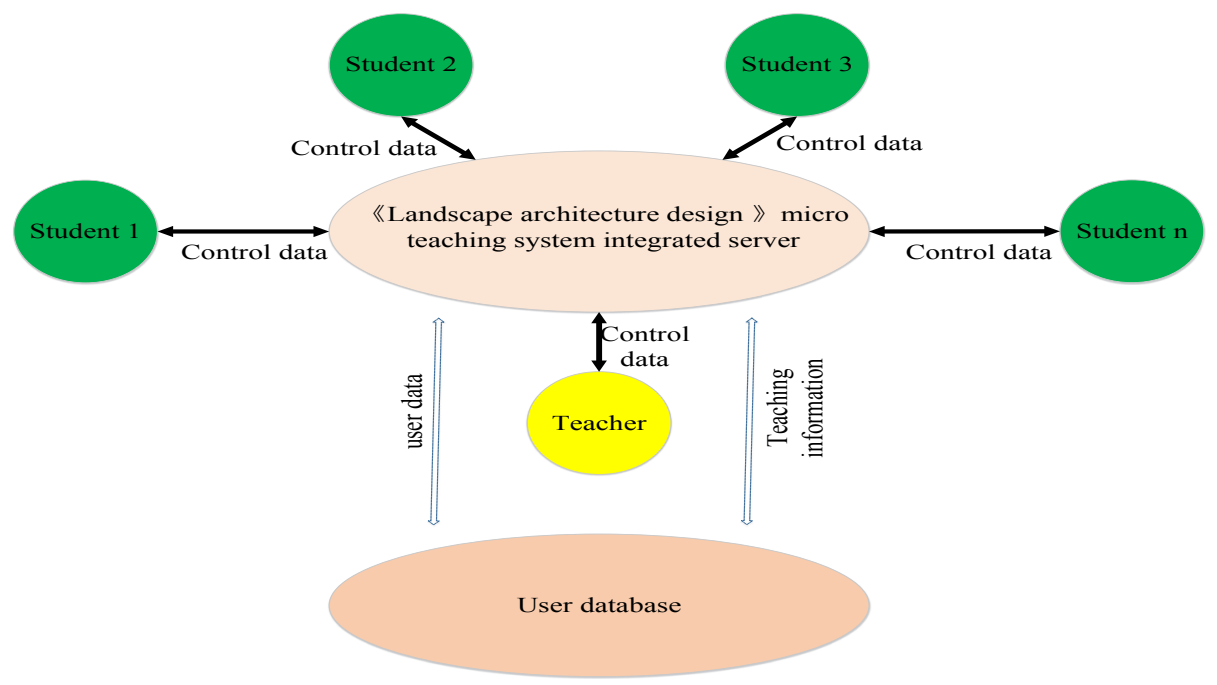

Fig. 3. Structure diagram of audio module

Firstly, product resource library of online micro-course platform of Garden Architecture Design should be designed. The resource library is composed of multimedia courseware library, course standard library, explanation-based online course library, question answering tutorship system library, material and case library etc. The contents mainly include architecture design theory, methods and skills of garden architecture design, pavilion design, service-based architecture design and design of garden architecture facilities etc. Content presentation modes include knowledge point text, exercise text, activity text, introduction graphs, teaching video, and discussion video etc. Library content uploading on the system backstage can be achieved in combination of 2D code technology.

Then, function points of technical means required by platform implementation are designed. Hardware equipment of online micro-course platform of Garden Architecture Design mainly includes smartphone, PAD, PC and so on. These hardware devices are utilized for 2D code scanning. The functions achieved include browsing, uploading, downloading, statistics, online exercise and social contact etc. teachers and students can exchange and study through the micro-course system, including some preview requirements, collection, uploading and sharing of garden architecture design data. Besides, text and voice forms may be used to ask questions, answer questions and discuss in micro-class. Teachers may simulate garden architecture situation through the system platform, and guide students to express their views on design problems. After class, teachers may publish practice task on the system platform, require students to complete the practice through cooperation, then transform the problems and specific solutions into the text and submit the text to the system. In the teaching evaluation link, teachers may encourage students to carry out self-assessment and mutual evaluation. 


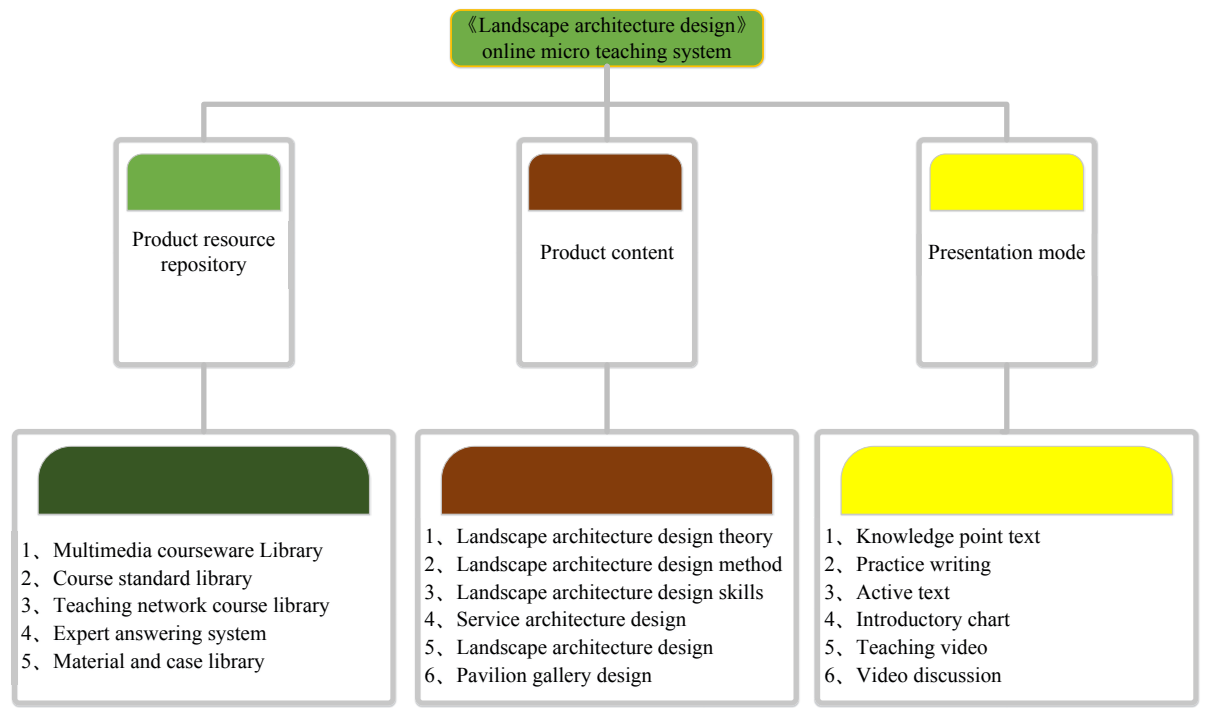

Fig. 4. Online micro-course teaching system products of Garden Architecture Design

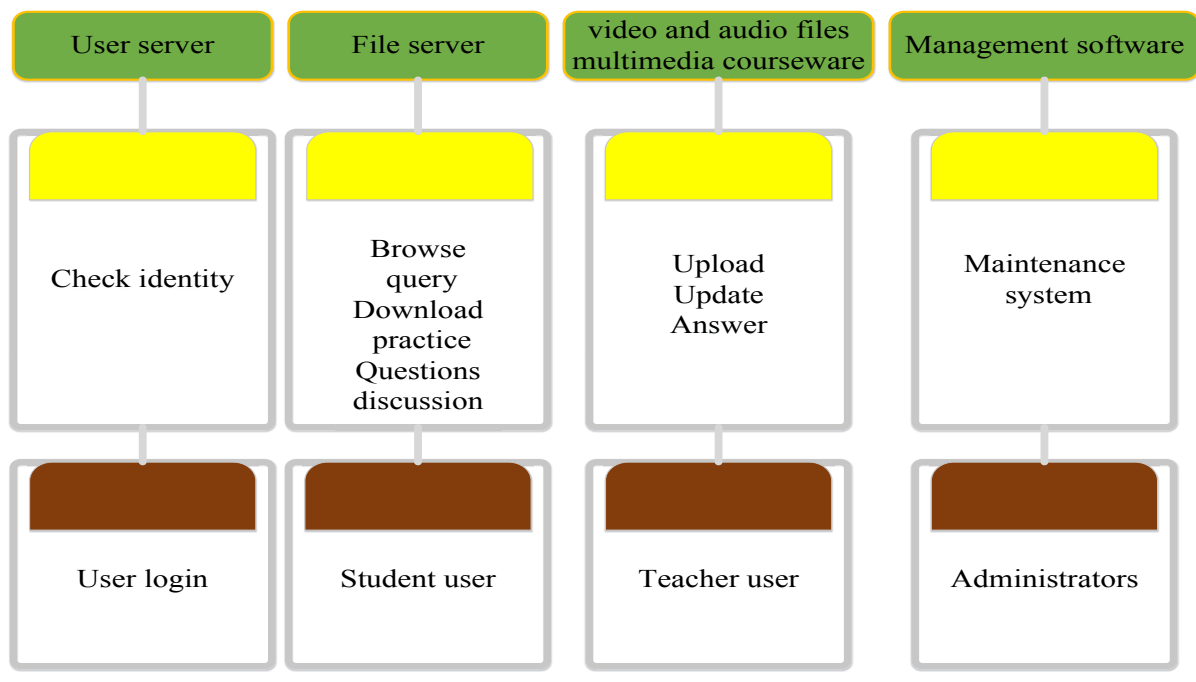

Fig. 5. Teaching function points of online micro-course of Garden Architecture Design

\subsection{Interface of micro-course teaching platform}

The login interface of online micro-course platform based on CPC model for Garden Architecture Design is shown in Fig.6. Teachers and students use the teacher number and student number to $\log$ in. since the micro-course is only open to the students of garden architecture design major, only the students of this major and relevant teachers can $\log$ in it. Except manual input of account number, this system may be 
entered through 3D code scanning. During scanning, the system backstage will recognize whether the user is the person of garden architecture design major.

The content interface of Garden Architecture Design is as follows. Each chapter has the sole 2D code. Through scanning the 2D code, students can enter the chapter to study.

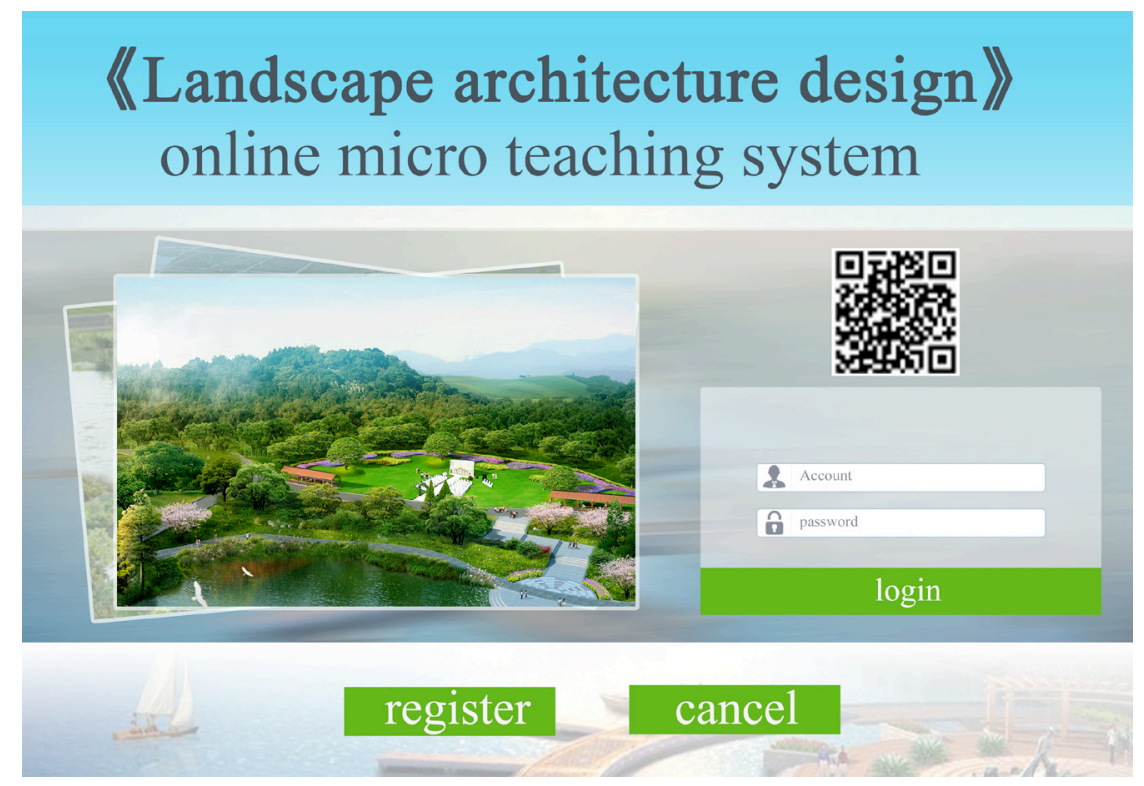

Fig. 6. Login interface of online micro-course system of Garden Architecture Design

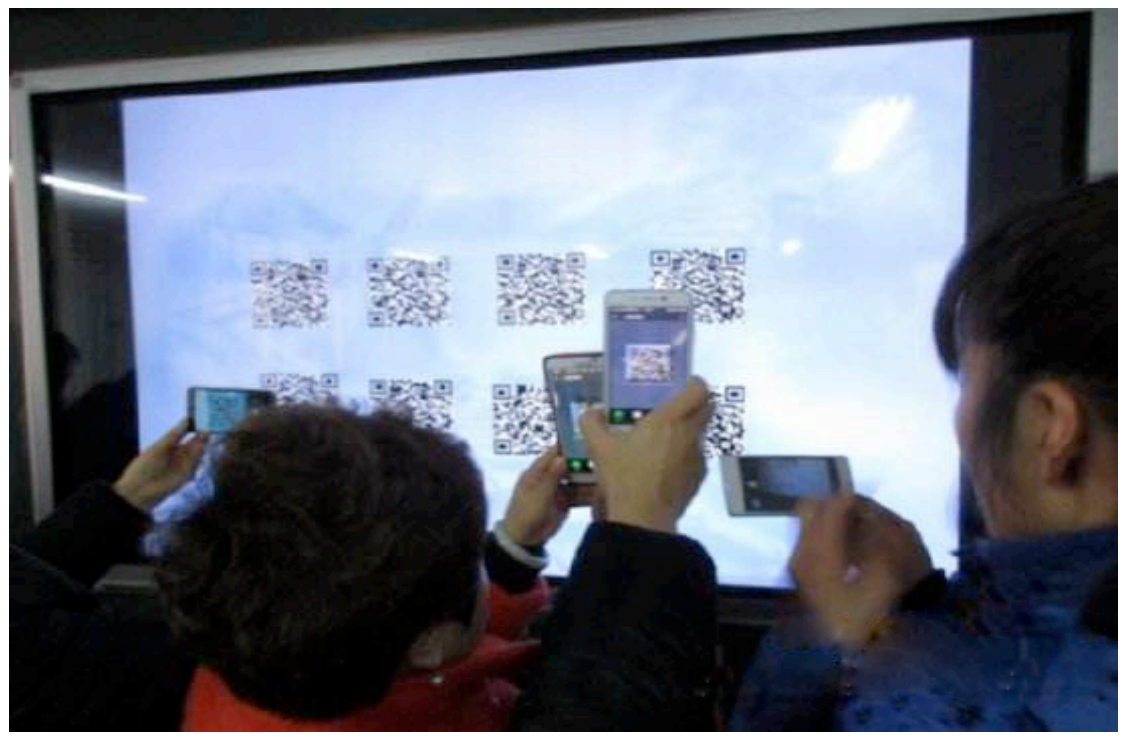

Fig. 7. Content interface of Garden Architecture Design 


\subsection{Effect analysis}

Experimental contrast and analysis were conducted for the system application. 1 semester was used as the time limit. Statistics of the scores of students of garden architecture design major in Grade 2015 was carried out. Besides, the questionnaire survey about their learning attitude was done. All students were divided into two groups. Online micro-course teaching system was adopted for the one group, and the other group served as the control group. The teaching objective, content, key point and difficult point where same. Score statistics for all students was made after the one semester, and questionnaire survey about their learning attitude was done to verify the application effect of online micro-course platform. The learning attitude questionnaire was gained through modifying the questionnaire designed by Zhang et al. [7]. The questionnaire adopted Likert5 score system, including 4 dimensions and 23 items. The total Cronbach's $\alpha$ coefficient was 0.927 . The 4 dimensions are as follows: cognition of design major ( 4 items, coefficient 0.855 ), learning experience (6 items, coefficient 0.874 ), learning interest ( 6 items, coefficient 0.861 ), and learning habit ( 7 items, coefficient 0.725 ).

Table 1. Comparison of mean score of learning attitude and score of each dimension for both groups $(\mathrm{x} \pm \mathrm{s})$

\begin{tabular}{|l|c|c|c|c|c|}
\hline \multicolumn{1}{|c|}{ Group } & Mean score & $\begin{array}{c}\text { Learning } \\
\text { interest }\end{array}$ & $\begin{array}{c}\text { Learning expe- } \\
\text { rience }\end{array}$ & $\begin{array}{c}\text { Learning } \\
\text { habit }\end{array}$ & $\begin{array}{c}\text { Cognition of the } \\
\text { major }\end{array}$ \\
\hline $\begin{array}{l}\text { Experimental group } \\
(\mathrm{N}=150)\end{array}$ & $3.62+0.62$ & $3.54+0.81$ & $3.79+0.80$ & $3.61+0.86$ & $3.40+0.98$ \\
\hline $\begin{array}{l}\text { Control group } \\
(\mathrm{N}=150)\end{array}$ & $3.21+0.75$ & $3.18+0.93$ & $3.43+0.88$ & $3.30+0.91$ & $2.93+0.87$ \\
\hline $\mathrm{P}$ & 0.043 & 0.035 & 0.006 & 0.040 & 0.022 \\
\hline
\end{tabular}

Tab.1 shows the learning attitude scores of experimental group and control group present significant differences. The questionnaire survey result indicates that after the introduction of micro-course, students improve greatly in the aspects of learning interest, experience, habit and cognition of the major. Hence, online micro-course platform based on CPC model can promote the change of students' learning attitude.

\section{Conclusions}

In one word, based on the development of modern information technology, many kinds of media software well assist Urban Planning teaching. Modern media software plays an irreplaceable role. But in the future teaching process, teachers should combine teaching contents to rationally apply advanced multimedia software. Meanwhile, teachers should guide students through properly setting teaching questions, visually process design problems, and directly point out students' shortcomings so as to avoid students' fuzzy cognition in complex space treatment and improve their space design ability. 


\section{Acknowledgment}

This work was supported in part by the Shaanxi Provincial Social Science Foundation (13SC031) and Special funds for basic research and operation expenses of Central Universities (310841170662).

\section{$7 \quad$ References}

[1] Lippényi, Z., Gerber, T.P. Inter-generational micro-class mobility during and after socialism: The power, education, autonomy, capital, and horizontal (PEACH) model in Hungary, Social Science Research, 2016, vol. 58, pp. 80-103. https://doi.org/10.1016/j.ssr esearch.2015.08.010

[2] Duke, A., Lieber, L., Studies, R., et al. Flipping the classroom, Physics Teacher, 2011, vol. 90(8), 507-507.

[3] Sánchez, A.C., Ferrer, P.V.C., Alaminos, M. Microteaching as a self-learning tool. Students' perceptions in the preparation and exposition of a microlesson in a tissue engineering course, Journal of Technology \& Science Education, 2013, vol. 3(2), pp. 66-72.

[4] Yu, L., Zhang, Y. Research on Application of Microlecture in Network Security Experiment Teaching, Wireless Internet Technology, 2015, vol. 11(4), pp. 446-450.

[5] George, D.R. "Friending Facebook?" A minicourse on the use of social media by health professionals, Journal of Continuing Education in the Health Professions, 2011, vol. 31(3), pp. 215-219. https://doi.org/10.1002/chp.20129

[6] Jacoby, D.B. An Innovative Integration of Genetics and Genomics Content into a Baccalaureate Nursing Curriculum: The Web-Based Mini-Course in Genetics and Genomics, 2014, vol. 1(2), pp. 79-84.

[7] Grubbs, M.E., Love, T.S., Long, D.E., et al. Science Educators Teaching Engineering Design: An Examination across Science Professional Development Sites, 2016, vol. 4(11), pp. $163-178$.

[8] He, L.P. The application of Autodesk Revit and Architecture software in Teaching, Jiaoshi Bolan, 2016, vol. 6(2), pp. 11-13.

[9] Li, K., Dai, D.M., Qiu, G. Research and application of integrating fragmented teaching resources based on information technology -- Taking steel pipe groove installation and valuation series as an example, China Information Technology Education, 2014, vol. 14(20), pp. 55-56.

[10] Peng, H., Xu, R. Design and implementation of teaching assistant platform for class training in Normal College Based on micro class model, Fujian computer, 2016, vol. 32(9), pp. 28-30.

[11] Bi, J.W. Product channel profit analysis of product channel customer considering the time value of money, Business Economy, 2016, vol. 20(1), pp. 41-42.

[12] Bian, J., Song, L.Y. Design of traceability system for the agricultural product based on RFID and Two-Dimensional code technology, Network Security Technology \& Application, 2010, vol. 11(10), pp. 49-52. 


\section{Author}

Lili Liu is an associate professor in the School of Architecture, Chang'an University, Xi’an 710064, China (13891858602@163.com).

Article submitted 12 March 2017. Published as resubmitted by the authors 5 June 2017. 